\title{
PENERAPAN MODEL PEMBELAJARAN TWO STAY TWO STRAY DALAM MENINGKATKAN KEAKTIFAN BELAJAR MATEMATIKA
}

\author{
Muhammad Mushfi El Iq Bali \\ Universitas Nurul Jadid Paiton Probolinggo \\ mushfieliqbali8@gmail.com
}

\begin{abstract}
The study aimed to improve the learning activeness of fourth-grade students through the application of the Two Stay Two Stray learning model. This research design is qualitative research. The instrument of data collection uses observation of teacher and student activities and interviews. The results of the study indicate that: this learning model must form groups of 4 people. Then discuss with the group that has been determined. After discussing, two people from each group visited other groups to get information on the results of discussions from each group. While the task of two members who settled in their group must give the results of their discussion to other groups. The learning process using the learning model Two Stay Two Stray can improve the learning activeness of fourth-grade students of MIN 1 Probolinggo. By using this learning model, students become enthusiastic in learning and they are no longer passive because each individual has their respective duties, so this learning model is declared successful in increasing student learning activeness.
\end{abstract}

Keywords: Learning Model, Two Stay Two Stray, Active Learning. 


\section{Pendahuluan}

Penggunaan metode dan model dalam pembelajaran mempunyai peran yang sangat signifikan dalam menentukan keberhasilan suatu pembelajaran. Karena dengan adanya metode dan model pembelajaran, pembelajaran akan lebih terarah dan menarik minat serta dapat mengorganisasikan kelas menjadi kelas yang aktif dan menyenangkan. Selama ini metode belajar konvensional masih mendominasi proses pembelajaran di sekolah, sehingga pebelajar terkadang merasa bosan dan tidak ada minat untuk belajar. Hal ini merupakan salah satu penyebab rendahnya prestasi belajar pebelajar.

Matematika merupakan muatan pelajaran memiliki jumlah jam pelajaran yang lebih daripada muatan pelajaran lain yang diajarkan di setiap sekolah. Suksesnya pembelajaran matematika dapat diukur dari ketuntasan pebelajar dalam mengikuti pelajaran tersebut. Keberhasilan itu dapat diukur dari segi pemahaman, penguasaan materi, dan prestasi belajar pebelajar. Namun dalam kenyataannya, antusias pebelajar dalam mengikuti pembelajaran matematika masih rendah. Pebelajar jarang mengajukan pertanyaan, meskipun pebelajar sering diberi kesempatan oleh pembelajar untuk bertanya hal-hal yang belum dipahami. Selain itu, kurangnya keberanian pebelajar untuk mengerjakan soal di depan kelas.

Pembelajaran yang berlangsung di sekolah kurang meningkatkan hasil belajar dan motivasi pebelajar dalam mata pelajaran matematika tidak selamanya berjalan dengan baik. Oleh karena itu, penyampaian materi pembelajaran, konsep-konsep dasar materi pembelajaran, serta beberapa faktor penugasan akademik yang dikerjakan harus disiasati dan direncanakan sedemikian rupa sehingga dengan hal itu pembelajar dapat meningkatkan hasil pembelajaran. ${ }^{1}$

Hasil observasi yang dilakukan pada tanggal 11 Oktober 2019 di kelas IV MIN 1 Probolinggo menunjukkan bahwa keaktifan belajar matematika masih rendah. Hal ini terbukti dengan masih banyaknya kondisi pebelajar yang pasif ketika pembelajaran dimulai. Pebelajar tampak berbicara sendiri dengan temannya dan tidak memperhatikan penjelasan pembelajar saat pembelajaran menjadi indikasi bahwa pembelajaran matematika yang dilakukan kurang maksimal dan cenderung membosankan.

Selain itu, kegiatan pembelajaran yang mengarah pada keaktifan belajar pebelajar kurang diterapkan. Hal ini terlihat saat diskusi kelompok pebelajar secara individu, pebelajar berkomunikasi hanya dengan kelompok tertentu dan enggan bekerja sama dengan pebelajar yang 1 Muhammad Mushfi El Iq Bali and Lailatul Rohmah, 'Implementasi Pendekatan
Eklektik Berbasis Sharing Zone', Murobbi: Jurnal Ilmu Pendidikan, 6.2 (2018), 152-167. 
memiliki kemampuan yang lebih baik. Pebelajar yang memiliki kemampuan akademis yang rendah, kurang dilibatkan dalam kegiatan berdiskusi dan menyelesaikan tugas secara berkelompok.

Upaya yang dapat dilakukan peneliti dalam mengatasi permasalahan yang berkaitan dengan peningkatan keaktifan pebelajar yaitu dengan menerapkan model pembelajaran kooperatif. Model pembelajaran kooperatif selain membantu pebelajar memahami konsepkonsep sulit juga dapat membantu pebelajar untuk menumbuhkan keterampilan sosial dan interpersonal skill dalam kelompoknya. Kagan and Kagan menyatakan bahwa pembelajaran kooperatif memiliki empat prinsip dasar yang membuat model ini berdampak positif terhadap pembelajaran, meliputi; positive interdependence (kesalingtergantungan positif), individual accountability (tanggung jawab individu), equal participation (partisipasi yang sama), simultaneous interaction (interaksi bersama). ${ }^{2}$

Model pembelajaran merupakan langkah-langkah pembelajaran yang disusun untuk digunakan dalam kegiatan pembelajaran agar pembelajaran dapat berlangsung dengan mudah dan dapat diterima dengan baik. Sebagaimana yang dikemukakan oleh Wahyubi bahwa model pembelajaran adalah sebuah cara yang dapat dilakukan untuk melaksanakan aktivitas pembelajaran agar terlaksana dengan baik dan sesuai harapan. ${ }^{3}$ Sedangkan Anitah \& Supriyati menyatakan bahwasanya model pembelajaran adalah sebuah cara yang telah dipikirkan secara mendalam untuk digunakan untuk mencapai sesuatu. Berdasarkan ketiga pendapat tersebut dapat diambil kesimpulan bahwa model pembelajaran adalah sebuah cara sistematis yang dipakai dalam menyampaikan materi pembelajaran kepada pebelajar. Model pembelajaran digunakan sebagai jalan mencapai tujuan pembelajaran. ${ }^{4}$

Model yang digunakan dalam memecahkan masalah ini yaitu model pembelajaran Two Stay Two Stray yang dikembangkan oleh Spencer Kagan. Model pembelajaran Two Stay Two Stray yaitu suatu pembelajaran yang tidak hanya terfokus dalam kelompok sendiri, melainkan juga antar kelompok melalui diskusi dengan saling diskusi dengan saling berbagi

\footnotetext{
${ }^{2}$ Muhammad Mushfi El Iq Bali, 'Penerapan Model Pembelajaran Fan N Pick Dan Two Stay Two Stray Untuk Meningkatkan Keterampilan Sosial Dan Hasil Belajar IPS Siswa', Jurnal Manajemen FE UM, 2015.

${ }^{3}$ Heri Wahyubi, 'Teori-Teori Belajar Dan Aplikasi Pembelajaran Motorik, Deskripsi Dan Tinjauan', (Bandung: Nusa Media, 2012), p. 236.

${ }^{4}$ Yetti Supriyati Sri Anitah, Strategi Pembelajaran Di SD, ed. by Sri Anitah \& Yetti Supriyati (Jakarta: Universitas Terbuka, 2008).
} 
hasil kegiatan kelompok. ${ }^{5}$ Model pembelajaran ini memberi kesempatan kepada semua kelompok untuk mengembangkan hasil diskusinya dengan kelompok lainnya. Selain itu, struktur Two Stay Two Stray ini memberi kesempatan kepada setiap kelompok untuk membagikan hasil diskusi kepada kelompok lain. Banyak kegiatan belajar mengajar yang dilakukan dengan kegiatan individu. Pebelajar bekerja sendiri dan tidak diperbolehkan melihat hasil pekerjaan pebelajar yang lain. Padahal, dalam kehidupan yang ssungguhnya di luar kegiatan sekolah, kehidupan dan kerja manusia saling berpengaruh dan saling bergantung antara satu dengan yang lainnya.

Proses belajar dapat menuntut seluruh untuk berperilaku aktif. Jadi, proses belajar berpusat pada pebelajar, sedangkan pembelajar hanya sebagai motivator dan fasilitator sehingga tercipta suasana kelas yang kondusif. Peningkatan keaktifan belajar siswa tidak akan terlepas dari berbagai macam faktor yang mempengaruhinya. Oleh karenanya, diperlukan seorang pembelajar/pendidik kreatif yang diharapkan dapat membuat belajar menjadi lebih menarik, bermakna, dan disukai oleh pebelajar. Dalam hal ini, keterampilan pembelajaran atau keterampilan mengajar menjadi hal paling utama bagi seorang pendidik dalam menciptakan proses pembelajaran yang lebih kreatif serta menyenangkan. Beberapa hal yang kiranya perlu diperhatikan oleh seorang pendidik agar pembelajaran dapat berjalan dengan baik, yaitu pebelajar yang ada dalam satu kelas biasanya mempunyai kemampuan yang tidak sama, serta model belajar yang berbeda pula. ${ }^{6}$

Dengan demikian, keaktifan belajar matematika adalah perubahan tingkah laku yang terjadi pada siswa dalam bidang matematika sebagai hasil yang dimiliki siswa selama mengikuti proses pembelajaran matematika. Keaktifan belajar inilah yang akan menjadi tolok ukur dan nantinya akan menentukan tingkat keberhasilan belajar siswa dalam mengetahui dan memahami suatu materi pelajaran matematika setelah mengalami pengalaman belajar yang dapat diukur melalui tes/ujian.

Secara teoritis, hasil penelitian ini dapat menambah pemahaman terhadap pendekatan teori dan strategi pembelajaran melalui model Two Stay Two Stray dalam meningkatkan keaktifan belajar pebelajar pada pembelajaran matematika. Sedangkan manfaat penelitian bagi kalangan pendidikan yaitu: pertama, hasil penelitian ini bagi pebelajar, dapat

\footnotetext{
${ }^{5}$ Muhammad Mushfi El Iq Bali, 'BINGO GAMES METHOD Upaya Meningkatkan Kemampuan Siswa Memecahkan Masalah Belajar Matematika', KEGURU: Jurnal Ilmu Pendidikan Dasar, 3.1 (2019), 48-59.

${ }^{6}$ Konstruksi Strategi, Pembelajaran Berbasis, and Multiple Intellegences, 'MULTIPLE INTELLIGENCES SEBAGAI UPAYA PEMECAHAN', Konstruksi Strategi Pembelajaran Berbasis Multiple Intellegences, 3.2 (2016), 1-12.
} 
meningkatkan keaktifan belajar pebelajar, menumbuhkan sikap kepedulian dan kerja sama dalam kelompok, dan dapat meningkatkan kemampuan pebelajar dalam mengemukakan dan menghargai pendapat orang lain. Pebelajar termotivasi dan percaya diri dalam berinteraksi sosial dalam bidang akademiknya.

Kedua, manfaat dari hasil penelitian ini bagi pembelajar yaitu dapat memperluas pengetahuan pembelajar mengenai metode pembelajaran yang dapat meningkatkan kualitas pembelajaran dan kualitas pembelajar dalam mengajar. Sehingga pembelajar semakin berkembang dalam hal inovasi metode pembelajaran yang diimplementasikan pada muatan ajar yang berbeda.

Ketiga, hasil penelitian ini memberikan faedah bagi sekolah ialah dapat memberikan sumbangsih pemikiran dalam meningkatkan kualitas pembelajaran, mutu sekolah, dan mutu pendidik. Hal ini dapat menunjang program-program sekolah dalam mewujudkan dan memenuhi kriteria lembaga pendidikan yang unggul dan empat aspek sekolah berkarakter adiwiyata.

Keempat, manfaat bagi peneliti yaitu dapat meningkatkan motivasi untuk terus belajar dan menambah wawasan serta pengalaman dalam mendidik, menambah pengetahuan khususnya dalam bidang pendidikan dalam meningkatkan keaktifan belajar pebelajar.

Dalam meningkatkan hasil belajarnya, pembelajar dapat menggunakan berbagai macam model pembelajaran sebagai usaha yang dilakukan pendidik untuk mengelola kelas dengan baik. Maksud dari kegiatan pengelolaan kelas ini adalah untuk mempertahankan agar suasana belajar di kelas tetap berlangsung dengan baik, efektif, dan efisien. ${ }^{7}$ Model pembelajaran Two Stay Two Stray merupakan model pembelajaran kelompok yang bertujuan supaya pebelajar mudah dalam berdiskusi, bertanggung jawab, saling membantu dalam menyelesaikan masalah dan saling memotivasi untuk berprestasi. Dengan model pembelajaran Two Stay Two Stray ini, pebelajar dilatih untuk aktif dalam muatan pelajaran matematika. Keterlibatan pebelajar untuk menggunakan model ini dapat membuat pembelajaran semakin bermakna.

\section{Metode Penelitian}

Desain penelitian ini adalah penelitian kualitatif. Alasan kualitatif dipilih karena tujuan dari penelitian ini adalah untuk membuat deskripsi, gambaran, atau lukisan secara sistematis, faktual, dan akurat mengenai

\footnotetext{
7 Abu Hasan Agus, 'Strategi Pengelolaan Kelas Dalam Proses Pembelajaran', Pedagogik; Jurnal Pendidikan, 3.1 (2015), 1-12.
} 
fakta-fakta, sifat, serta hubungan antar fenomena yang diselidiki. Penelitian ini akan memberikan gambaran secara kualitatif terhadap penerapan model Two Stay Two Stray dalam meningkatkan keaktifan belajar pebelajar pada pembelajaran matematika.

Jenis penelitian ini adalah studi kasus (case study). Studi kasus adalah penelitian yang dilakukan dengan menggali informasi yang bisa dipelajari atau ditarik dari sebuah kasus, baik kasus tunggal maupun jamak. Agar sebuah kasus bisa digali maknanya, peneliti harus pandai-pandai memilih semacam kasus yang layak diangkat menjadi tema penelitian. Bobot kualitas kasus harus menjadi pertimbangan utama. Dengan demikian, tidak semua persoalan atas kasus baik pada tingkat perorangan, kelompok atau lembaga bisa dijadikan bahan kajian studi kasus. Begitu juga tidak setiap pertanyaan bisa diangkat menjadi pertanyaan penelitian (research question). ${ }^{8}$

Penelitian ini berlokasi di MIN 1 Probolinggo yang beralamat di Jalan Raya Panglima Sudirman Kecamatan Paiton Kabupaten Probolinggo pada kelas IV semester ganjil tahun ajaran 2019/2020, dengan jumlah siswa 17 orang yang terdiri dari 8 pebelajar laki-laki dan perempuan berjumlah 9 orang dengan kemampuan akademik yang berbeda atau heterogen. Selain itu, kelas ini diketahui keaktifan pebelajar yang masih rendah.

Data diperoleh selama proses pembelajaran di kelas sejak penelitian dilakukan. Adapun data yang diambil dalam penelitian ini sebagai berikut; pertama, data tentang aktivitas pembelajar dan pebelajar selama pembelajaran kooperatif Two Stay Two Stray. Kedua, data tentang keaktifan pebelajar setelah mengikuti pembelajaran Two Stay Two Stray. Ketiga, data tentang respon pebelajar terhadap pembelajaran Two Stay Two Stray. Sedangkan sumber data diperoleh dari pebelajar dan pembelajar yang meliputi hasil observasi selama kegiatan belajar mengajar.

Data yang dikumpulkan dalam penelitian ini meliputi observasi non partisipan, wawancara (interview), catatan lapangan, dan dokumentasi berupa foto proses pembelajaran. Tahapan analisis data meliputi; pengumpulan data, reduksi data, display data, dan penarikan kesimpulan (verifikasi). Analisis data dilaksanakan sejak awal penelitian hingga data terkumpul, kemudian dianalisis untuk memastikan bahwa penerapan model pembelajaran Two Stay Two Stray dapat meningkatkan keaktifan belajar matematika pebelajar di kelas IV MIN 1 Probolinggo.

\section{Hasil dan Pembahasan} ${ }^{8}$ Mudjia Rahardjo, 'No Title', ed. by Mudjia Raharjo, Studi Kasus Dalam Penelitian
Kualitatif Konsep Dan Prosedurnya (Malang: Universitas Malang, 2017), pp. 1-28. 
Berdasarkan observasi selama pelaksanaan penelitian, diperoleh hasil penelitian menunjukkan peningkatan pada beberapa aspek indikator yang ditetapkan meliputi: pertama, keterlaksanaan model pembelajaran Two Stay Two Stray oleh pembelajar dan pebelajar. Kedua, keaktifan belajar matematika pebelajar.

Model Pembelajaran Two Stay Two Stray dapat mengubah sikap pebelajar dari pasif menjadi aktif, karena dengan model pembelajaran ini pebelajar mempunyai tugas masing-masing sehingga tidak ada pebelajar yang pasif. Keterlaksanaan model pembelajaran Two Stay Two Stray oleh pembelajar dan pebelajar dikategorikan sangat baik sehingga dinyatakan berhasil. Pebelajar mengalami peningkatan dalam keaktifan di kelas. Penerapan model pembelajaran Two Stay Two Stray dapat meningkatkan keaktifan belajar pebelajar.

\section{Penerapan Model Pembelajaran Two Stay Two Stray untuk Meningkatkan Keaktifan Belajar Matematika Pebelajar MIN 1 Probolinggo}

Muatan pelajaran matematika pada umumnya dianggap sulit dalam mempelajarinya. Padahal ketika pelajaran itu disampaikan dengan model pembelajaran yang baik dan menyenangkan, maka pelajaran tersebut akan mudah dipahami. Dalam setiap penyampaian materi, pembelajar perlu menggunakan model pembelajaran yang bervariasi. Model pembelajaran ini disesuaikan dengan materi pelajaran, situasi, dan kondisi dalam pembelajaran sehingga materi dapat tersampaikan dengan baik.

Penerapan model pembelajaran Two Stay Two Stray yang ada di MIN 1 Probolinggo telah berjalan dengan baik dan sesuai dengan teori yang ada, yakni sebagai berikut; pertama, menyusun langkah-langkah model pembelajaran Two Stay Two Stray. Penerapan model pembelajaran Two Stay Two Stray yang ada di MIN 1 Probolinggo sudah berjalan dengan baik. Langkah-langkah yang dilakukan oleh pembelajar dalam penerapan model Two Stay Two Stray ini adalah berawal dari menyiapkan model pembelajaran, hingga menerapkan model pembelajaran Two Stay Two Stray ini di dalam kelas. Pembelajar muatan pelajaran matematika di MIN 1 Probolinggo ini sangat menekankan untuk selalu menyusun langkah-langkah model pembelajaran Two Stay Two Stray sebelum melaksanakan pembelajaran agar pembelajaran dapat berlangsug efektif dan dapat mencapai tujuan pembelajaran.

Kedua, pembelajar memberikan motivasi kepada pebelajar agar dapat menerima materi dengan baik. Pemberian motivasi sangat penting disampaikan oleh seorang pembelajar, guna memicu semangat belajar pebelajar. Mc. Donald mendefinisikan motivasi belajar sebagai suatu perubahan energi di dalam pribadi seseorang yang ditandai dengan 
timbulnya afektif dan reaksi untuk mencapai tujuan. ${ }^{9}$ Jadi, motivasi dapat dikatakan sebagai suatu usaha atau kekuatan yang timbul dari dalam dan mendorong seseorang untuk melakukan kegiatan dalam mencapai tujuan tertentu.

Ketiga, pembelajar menjelaskan tujuan pembelajaran. Tujuan pembelajaran amat penting disampaikan kepada pebelajar sebelum pembelajar memulai pembelajaran. Penyampaian tujuan pembelajaran merupakan tujuan yang menggambarkan pengetahuan, kemampuan, keterampilan, dan sikap yang harus dimiliki pebelajar sebagai akibat dari hasil pembelajaran yang dinyatakan dalam bentuk tingkah laku yang dapat diamati dan diukur. Tujuan pembelajaran memang perlu dirumuskan dengan jelas karena perumusan tujuan yang jelas dapat digunakan sebagai tolok ukur keberhasilan dari proses pembelajaran itu sendiri. Oleh karena itu, seorang pembelajar perlu menyampaikan tujuan pembelajaran kepada pebelajar, sehingga pebelajar menjadi lebih serius dalam mengikuti dan menyimak materi yang diberikan.

Keempat, pembelajar memperkenalkan dan menerapkan model pembelajaran Two Stay Two Stray. Sebelum materi disampaikan dengan sebuah model pembelajaran, maka pembelajar perlu menjelaskan model yang akan diterapkan terlebih dahulu agar pebelajar bisa lebih mudah mengikuti pembelajaran. Penerapan model pembelajaran Two Stay Two Stray untuk menanamkan konsep matematika ini dianggap perlu dalam rangka meningkatkan hasil belajar pebelajar. Pembelajar dapat mengkondisikan iklim pembelajaran yang bermakna (meaningfull learning) dan menyenangkan, sehingga pebelajar terus bergembira dan tidak membosankan.

Dengan demikian, model pembelajaran Two Stay Two Stray mendorong semua pebelajar untuk ikut berpartisipasi secara langsung dalam kegiatan belajar mengajar. Kegiatan ini merupakan kegiatan yang efektif. Disamping itu, model pembelajaran Two Stay Two Stray merupakan model pengajaran yang mempunyai tujuan ingin lebih meningkatkan kemampuan berpikir dan keaktifan siswa. Hal ini sesuai dengan pernyataan pembelajar bahwa nilai matematika pebelajar mengalami perkembangan (peningkatan) yang signifikan setelah menerapkan model Two Stay Two Stray dalam pembelajaran matematika. Sehingga model pembelajaran ini menjadi efektif dan mudah dalam mencapai tujuan pembelajaran.

\footnotetext{
${ }^{9}$ Syaiful Islam and others, 'To Boost Students' Motivation and Achievement through Blended Learning', in Journal of Physics: Conference Series (Institute of Physics Publishing, 2018), mcxiv, 1-11.
} 


\section{Kelebihan dan Kelemahan dalam Penerapan Model Pembelajaran Two Stay Two Stray di MIN 1 Probolinggo}

Adapun kelebihan dalam penerapan model Two Stay Two Stray di MIN 1 Probolinggo adalah sebagai berikut; pertama, Pebelajar sangat antusias mengerjakan tugas yang diberikan oleh pembelajar. Pembelajaran matematika dengan menggunakan model pembelajaran Two Stay Two Stray dapat meningkatkan antusias pebelajar dalam mengerjakan tugas-tugas yang diberikan oleh pembelajar. Pebelajar merasa senang dan sangat tertarik untuk memecahkan soal-soal yang diberikan pembelajar.

Kedua, pebelajar dapat menciptakan kreatifitas dalam melakukan komunikasi dengan tema sekelompoknya. Model pembelajaran Two Stay Two Stray ini mendorong pebelajar melakukan komunikasi sesuai dengan tema dan ide kelompoknya. Selain itu, pebelajar juga bisa berdiskusi secara berkelompok dengan kelompok lain. Jadi, dapat dilakukan dengan mudah dan sesuai dengan karakter pebelajar.

Ketiga, pebelajar merasa lebih mudah dalam belajar. Penerapan model Two Stay Two Stray di MIN 1 Probolinggo dapat membuat siswa merasa lebih mudah dalam belajar matematika. Berdasarkan hasil wawancara terhadap pebelajar mengenai kegiatan pembelajaran menggunakan model Two Stay Two Stray, bahwa pebelajar lebih mudah dalam memahami konsep materi matematika karena bisa dilakukan dengan cara yang sederhana dan menyenangkan. Model Two Stay Two Stray ini juga menunjukkan keaktifan belajar pebelajar menjadi lebih baik.

Keempat, pebelajar tidak merasa tegang saat pembelajaran. Saat pembelajaran matematika, mayoritas pebelajar tidak menyukai muatan pelajaran tersebut. Muatan pelajaran matematika dianggap susah bagi pebelajar untuk dipahami karena agak rumit, sehingga menyebabkan pebelajar kurang antusias dan malas bahkan takut masuk kelas karena tidak paham materi yang dijelaskan oleh pembelajar. Pebelajar merasa muatan pelajaran matematika menjadi suatu hal yang menakutkan karena banyak materi yang susah untuk dipahami. Pembelajar matematika yang lebih terkenal dengan pembelajar killer, membuat pebelajar selalu tegang saat menghadapi muatan pelajaran matematika.

Namun, semenjak pembelajaran matematika menggunakan model pembelajaran Two Stay Two Stray, rasa ketakutan pebelajar menjadi berkurang bahkan pebelajar menjadi bersemangat. Sesuai dengan pendapat Wakil Ketua Kurikulum yang menyampaikan bahwa pelajaran yang dirasa sangat sulit, apabila dikemas dalam model pembelajaran yang menyenangkan, maka akan merubah mindset pebelajar untuk meningkatkan semangat belajar mereka. 
Kelima, pebelajar lebih kompak dan lebih percaya diri dalam mengikuti pembelajaran. Model pembelajaran Two Stay Two Stray mampu membuat pebelajar lebih kompak dan percaya diri. Pebelajar lebih semangat dan mampu menanamkan konsep materi yang awalnya tidak paham menjadi mudah dipahami dan menjawab jika pebelajar sudah paham sehingga diskusi berjalan dengan lancar. Dalam model pembelajaran ini, siswa berperan aktif dalam proses pembelajaran sehingga proses pembelajaran tidak monoton dan siswa lebih bersemangat untuk mengikuti proses pembelajaran.

Keenam, pebelajar dapat meningkatkan kemampuan dalam berbicara. Belajar matematika dengan menggunakan model Two Stay Two Stray dengan membentuk kelompok dan berdiskusi dapat meningkatkan pebelajar untuk berbicara. Model pembelajaran Two Stay Two Stray tidak serta merta dicetuskan begitu saja, tetapi ada uji coba untuk memastikan apakah model pembelajaran tersebut dapat digunakan ataukah tidak.

Ketujuh, meningkatkan minat dan prestasi belajar pebelajar. Model pembelajaran Two Stay Two Stray merupakan model pembelajaran yang sangat menarik bagi pebelajar. Dengan membentuk kelompok dan saling bertamu ke kelompok lain dapat menarik minat pebelajar untuk belajar dan beraktivitas. Aktivitas pebelajar dalam kegiatan kelompok yang dilakukan dengan gembira menciptakan suasana belajar yang menyenangkan dan bermakna (meaningfull learning). Sesuai dengan pernyataan pebelajar bahwa pebelajar awalnya tidak menyukai mempelajari muatan pelajaran matematika, berkat model pembelajaran Two Stay Two Stray pebelajar menjadi suka dan senang ketika belajar muatan pelajaran matematika.

Sedangkan kelemahan dalam penerapan model Two Stay Two Stray di MIN 1 Probolinggo adalah sebagai berikut; pertama, waktu yang dibutuhkan lebih lama terutama bagi pebelajar yang belum memahami langkah-langkah model pembelajaran Two Stay Two Stray. Oleh karena itu, pembelajar perlu mengenalkan dan memastikan bahwa pebelajar telah benar-benar memahami sintaks model pembelajaran Two Stay Two Stray.

Kedua, pebelajar yang tidak biasa melakukan belajar kelompok merasa asing dan sulit untuk bekerjasama, sehingga pebelajar cenderung malas untuk kerja kelompok. Pembelajar perlu menerapkan, melatih, dan membiasakan pebelajarnya untuk saling bekerjasama dalam proses pembelajaran sehingga hubungan interaksi sosial dan percaya diri pebelajar terwujud dan aktif.

Ketiga, pembelajar kurang memberi kesempatan waktu untuk memberi kontribusi individu. Kontribusi individu yang dimaksud adalah kemampuan bertanya, percaya diri, dan kemampuan memberikan pendapat dan kritik yang membangun dalam kegiatan belajar kelompok. 
Untuk mengatasi kekurangan model pembelajaran Two Stay Two Stray, maka sebelum pelaksanaan pembelajaran pembelajar harus mempersiapkan dengan sebaik mungkin dan membentuk kelompokkelompok belajar secara heterogen yang ditinjau dari jenis kelamin pebelajar dan kemampuan akademis pebelajar. Berdasarkan dari jenis kelamin, dalam satu kelompok harus terdiri dari pebelajar laki-laki dan perempuan. Sedangkan menurut kemampuan akademis, dalam satu kelompok terdiri dari satu orang yang memiliki kemampuan akademis tinggi, memiliki kemampuan akademis tinggi terdiri dari satu orang, memiliki kemampuan akademis sedang sebanyak dua orang, dan memiliki kemampuan akademis kurang sebanyak dua orang. Pembentukan kelompok heterogen ini dapat memudahkan dalam pengelolaan kelas, karena terdapat satu orang yang memiliki akademis tinggi sehingga dapat membantu anggota kelompoknya untuk memecahkan masalah yang dihadapi saat diskusi dalam penerapan model pembelajaran Two Stay Two Stray.

Implikasi dari penerapan model pembelajaran Two Stay Two Stray ini, pebelajar merasa muatan pelajaran matematika menjadi tidak membosankan lagi, bahkan pebelajar merasa senang karena muatan pelajaran matematika lebih mudah untuk dipahami. Menciptakan pembelajaran menjadi sesuatu yang menyenangkan itu adalah suatu keharusan bagi seorang pembelajar, namun untuk menciptakannya bukanlah suatu hal yang mudah. ${ }^{10}$ Pembelajar harus menciptakan iklim pembelajaran yang dikemas dengan hal-hal yang menarik perhatian pebelajar, membuat pebelajar senang melakukannya, dan tidak merasa bosan.

\section{Kesimpulan}

Berdasarkan hasil penelitian tentang hal-hal yang berkaitan dengan penelitian ini, maka sebagai akhir pembahasan peneliti akan memberikan kesimpulan sebagai berikut: pertama, Penerapan model pembelajaran Two Stay Two Stray pada muatan pelajaran matematika di MIN 1 Probolinggo meliputi: (1) Pembelajar menyusun langkah-langkah model pembelajaran Two Stay Two Stray; (2) Pembelajar memberikan motivasi kepada pebelajar agar dapat menerima materi dengan baik; (3) Pembelajar menjelaskan tujuan pembelajaran; (4) Pembelajar menjelaskan konsep pembelajaran Two Stay Two Stray; dan (5) Pembelajar memperkenalkan dan menerapkan model pembelajaran Two Stay Two Stray. Model pembelajaran Two Stay Two Stray mampu meningkatkan keaktifan belajar pebelajar kelas IV di ${ }^{10}$ Dewi Oktavia and others, 'Exploration of Fine Motor Skills through the Application
of Paint', in WESTECH (European Alliance for Innovation n.o., 2019), pp. 1-6. 
MIN 1 Probolinggo. Pebelajar menjadi lebih antusias dan bersemangat mengikuti dan memahami konsep materi muatan pelajaran matematika.

Kedua, Adapun kelebihan dalam penerapan Model Pembelajaran Two Stay Two Stray dalam meningkatkan keaktifan belajar pebelajar pada muatan pelajaran matematika kelas IV di MIN 1 Probolinggo yaitu: (1) Pebelajar dapat memecahkan permasalahan dengan menentukan konsep sendiri; (2) Pebelajar dapat menciptakan kreatifitas dalam melakukan komunikasi dengan tema sekelompoknya; (3) Pebelajar merasa lebih mudah dalam belajar; (4) Ketika pelaksanaan pembelajaran pebelajar tidak tegang dan lebih aktif mengikuti kegiatan tersebut; (5) Pebelajar lebih berani mengungkapkan pendapatnya; (6) Pebelajar lebih kompak dan lebih percaya diri dalam mengikuti pembelajaran; (7) Pebelajar dapat meningkatkan kemampuan dalam berbicara; dan (8) Meningkatkan minat dan prestasi belajar pebelajar. Ketiga, Adapun kelemahan dalam penerapan model pembelajaran Two Stay Two Stray terhadap keaktifan belajar pada muatan pelajaran matematika di MIN 1 Probolinggo mencakup: (1) Membutuhkan waktu yang lebih lama; (2) Pebelajar yang tidak biasa melakukan belajar kelompok merasa asing dan sulit untuk bekerjasama sehingga pebelajar cenderung malas untuk kerja kelompok; dan (3) Pembelajar kurang memberikan kesempatan waktu untuk memberi kontribusi tambahan materi pelajaran terhadap individu.

\section{Saran}

Berdasarkan kesimpulan yang telah diuraikan di atas, saran yang dapat diajukan terkait penerapan model Two Stay Two Stray terhadap keaktifan belajar pada pembelajaran matematika di MIN 1 Probolinggo antara lain; (a) Pebelajar dapat mempertahankan dan lebih meningkatkan lagi keaktifan belajar yang sudah baik dengan terus belajar, (b) Pembelajar hendaknya dapat menggunakan model pembelajaran yang tepat dan bervariatif dalam proses pembelajaran, sehingga dapat menarik minat belajar pebelajar dan meningkatkan antusias pebelajar dalam proses pembelajaran, salah satunya model pembelajaran Two Stay Two Stray, dan (c) Sekolah yang ingin menerapkan model Two Stay Two Stray dalam pembelajaran hendaknya memberikan dukungan kepada pembelajar berupa perlengkapan fasilitas sekolah yang mendukung tercapainya pembelajaran ini secara maksimal.

\section{Daftar Pustaka}

Agus, Abu Hasan, 'Strategi Pengelolaan Kelas Dalam Proses Pembelajaran', Pedagogik; Jurnal Pendidikan, 3 (2015), 1-12. 
Arikunto, Suharsimi, 'Pengelolaan Kelas dan Siswa Sebuah Pendekatan Evaluatif' (Jakarta: Rineka Cipta, 2006).

Bali, Muhammad Mushfi El Iq, 'BINGO GAMES METHOD Upaya Meningkatkan Kemampuan Siswa Memecahkan Masalah Belajar Matematika', KEGURU: Jurnal Ilmu Pendidikan Dasar, 3 (2019), 48-59.

, 'Penerapan Model Pembelajaran Fan N Pick Dan Two Stay Two Stray Untuk Meningkatkan Keterampilan Sosial Dan Hasil Belajar IPS Siswa', Jurnal Manajemen FE UM, 2015.

Bali, Muhammad Mushfi El Iq, and Lailatul Rohmah, 'Implementasi Pendekatan Eklektik Berbasis Sharing Zone', Murobbi: Jurnal Ilmu Pendidikan, 6 (2018), 152-167.

Huda, Miftahul, 'Model-Model Pengajaran dan Pembelajaran: Isu-isu Metodis dan Paradigmatis' (Yogyakarta: Pustaka Belajar, 2013).

Islam, Syaiful, Hasan Baharun, Chusnul Muali, Moh Idil Ghufron, Muhammad Mushfi El Iq Bali, Mualim Wijaya, and others, 'To Boost Students' Motivation and Achievement through Blended Learning', in Journal of Physics: Conference Series (Institute of Physics Publishing, 2018), MCXIV, 1-11 $<$ https://doi.org/10.1088/1742-6596/1114/1/012046>.

Moleong, J Lexy, 'Metodologi Penelitian Kualitatif cet. 35' (Bandung: PT. Remaja Rosdakarya, 2016).

Mulyasa, E, 'Menjadi Guru Profesional' (Bandung: Remaja Rosdakarya, 2011).

Nasution, S, 'Metode Research (Penelitian Ilmiah)' (Jakarta: PT. Bumi Aksara, 2008).

Oktavia, Dewi, Muhammad Mushfi El Iq Bali, Handono Rahman, Umar Umar, Agus Syakroni, and Faizatul Widat, 'Exploration of Fine Motor Skills through the Application of Paint', in WESTECH (European Alliance for Innovation n.o., 2019), pp. 1-6 <https://doi.org/10.4108/eai.8-12-2018.2284038>.

Rahardjo, Mudjia, 'No Title', ed. by Mudjia Raharjo, Studi Kasus Dalam Penelitian Kualitatif Konsep Dan Prosedurnya (Malang: Universitas Malang, 2017), pp. 1-28.

Rahyubi, Heri, 'Teori-teori Belajar dan Aplikasi Pembelajaran Motorik, Deskripsi dan Tinjauan' (Bandung: Nusa Media, 2012).

Saebani, Ahmad Beni, 'Metode Penelitian' (Bandung: CV. Pustaka Setia, 2016).

Shoimin, Arif, 'Model Pembelajaran' (Yogyakarta: Ar-ruzz Media, 2014). Sri Anitah, Yetti Supriyati, Strategi Pembelajaran Di SD, ed. by Sri Anitah \& Yetti Supriyati (Jakarta: Universitas Terbuka, 2008). 
Strategi, Konstruksi, Pembelajaran Berbasis, and Multiple Intellegences, 'MULTIPLE INTELLIGENCES SEBAGAI UPAYA PEMECAHAN', Konstruksi Strategi Pembelajaran Berbasis Multiple Intellegences, 3 (2016), 1-12.

Sukmadinata, Nana S, 'Metode Penelitian Pendidikan Cet. 7' (Bandung: PT. Remaja Rosdakarya, 2011).

Suprijono, Agus, 'Cooperatif Learning; Teori \& Aplikasi PAIKEM' (Yogyakarta: Pustaka Pelajar, 2011).

Wahyubi, Heri, 'Teori-Teori Belajar Dan Aplikasi Pembelajaran Motorik, Deskripsi Dan Tinjauan', (Bandung: Nusa Media, 2012), p. 236. 